\title{
Unusual breast cancer metastasis
}

\author{
Nuno André Barros, Arlindo Ferreira, Maria José Rocha, Luis Castro
}

Departments of Obstetrics and Gynecology, Hospital de Braga, Braga, Portugal

\section{Correspondence to} Dr Nuno André Barros, nunobarros@mail.com

Accepted 22 May 2015

\section{DESCRIPTION}

Invasive ductal carcinoma (IDC) is the most common histological type of breast cancer, accounting for up to $85 \%$ of all invasive breast carcinomas. ${ }^{1}$ In IDC, the most common areas of solitary metastasis are lung, liver, brain and bone.

In a study published by Borst and Ingold, ${ }^{2}$ referring to the metastatic patterns of breast cancer in a group of 2246 patients with ICD, no one presented with adrenal metastasis.

Adrenal metastases of breast cancer are usually associated with invasive lobular carcinoma (ILC), most often synchronous with multiorgan metastasis. ${ }^{3}$ Isolated adrenal metastases are rare in carcinomas of the breast, especially when they originate from IDCs.

There has only been one case of solitary adrenal metastasis in IDC $^{4}$ published (online PubMed search).

We report a case of a 66-year-old woman with a history of IDC (pTNM: pT2G3N1aMx-stage IIB) treated with modified radical mastectomy, chemotherapy and radiotherapy, followed by hormone therapy with tamoxifen.

In her follow-up consultation 5 years after the initial treatment, she presented with right hypochondriac pain. After a normal abdominal ultrasound and bone cintilogram, she had a positron emission tomography scan performed, which showed a right adrenal mass (figure 1). The CT

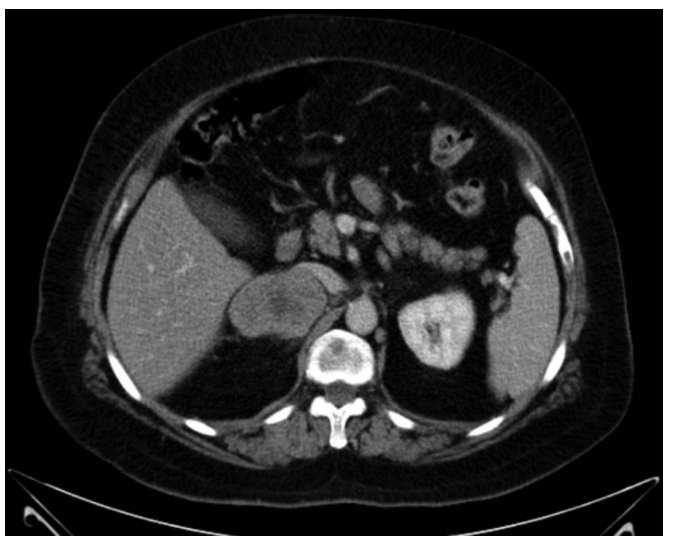

Figure 2 Abdominopelvic CT scan: right adrenal mass (coronal plane).

scan confirmed the presence of a $7 \times 4 \mathrm{~cm}$ mass on the right adrenal gland (figure 2).

The patient underwent total right adrenalectomy. The postoperative histopathological finding confirmed an IDC of the breast metastasis.

This is a report of an extremely rare case of solitary adrenal metastasis of an IDC who presented 5 years after the initial treatment. Given the rarity of solitary adrenal metastasis, the recommended treatment is still unclear, and must be individualised.

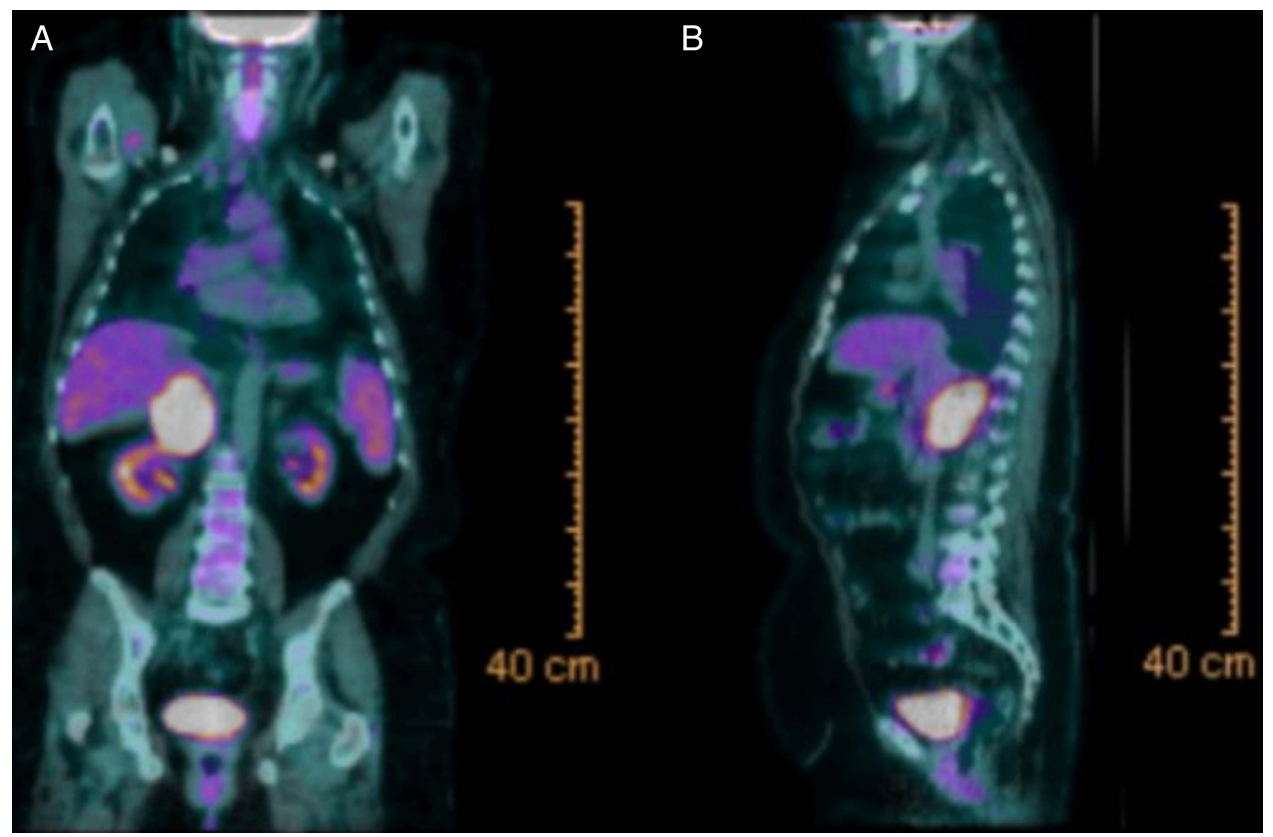

Figure 1 Positron emission tomography scan: right adrenal mass (A) coronal plane, (B) sagittal plane. 


\section{Learning points}

Solitary adrenal metastasis can rarely occur after invasive ductal carcinoma of the breast.

- Clinicians must be prepared to diagnose rare sites of metastasis after initial breast cancer treatment.

- Total adrenalectomy is a treatment option in cases of solitary adrenal metastasis.

Acknowledgements The authors would like to acknowledge the collaboration of the Department of Surgery.

Contributors NAB and MJR followed up the patient in the outpatient clinic. NAB, $A F, M J R$ and $L C$ evaluated the patient. MJR, $A F$ and $L C$ performed the surgery. NAB collected the data and wrote the manuscript. All the authors were involved in the conception of the work and revised it critically for important intellectual content as well. The authors approved the final version to be submitted/published.

Competing interests None declared.

Patient consent Obtained.

Provenance and peer review Not commissioned; externally peer reviewed.

\section{REFERENCES}

1 Toikkanen S, Pylkkänen $\mathrm{L}$, Joensuu $\mathrm{H}$. Invasive lobular carcinoma of the breast has better short- and long-term survival than invasive ductal carcinoma. $\mathrm{Br} J$ Cancer 1997:76:1234-40

2 Borst MJ, Ingold JA. Metastatic patterns of invasive lobular versus invasive ductal carcinoma of the breast. Surgery 1993;114:637-41; discussion 641-2.

3 Bumpers $\mathrm{HL}$, Hassett JM, Penetrante RB, et al. Endocrine organ metastases in subjects with lobular carcinoma of the breast. Arch Surg 1993;128:1344-7.

4 Liu XJ, Shen P, Wang XF, et al. Solitary adrenal metastasis from invasive ductal breast cancer: an uncommon finding. World J Surg Oncol 2010;8:7.

Copyright 2015 BMJ Publishing Group. All rights reserved. For permission to reuse any of this content visit http://group.bmj.com/group/rights-licensing/permissions.

BMJ Case Report Fellows may re-use this article for personal use and teaching without any further permission.

Become a Fellow of BMJ Case Reports today and you can:

- Submit as many cases as you like

- Enjoy fast sympathetic peer review and rapid publication of accepted articles

- Access all the published articles

- Re-use any of the published material for personal use and teaching without further permission

For information on Institutional Fellowships contact consortiasales@bmjgroup.com

Visit casereports.bmj.com for more articles like this and to become a Fellow 